\title{
Zooplankton Distribution and Community Structure in the Pacific and Atlantic Sectors of the Southern Ocean during Austral Summer 2017-18: A Pilot Study Conducted from Ukrainian Long-Liners
}

\author{
Evgeny A. Pakhomov 1,2,3,*, Leonid K. Pshenichnov ${ }^{4}$, Anatoly Krot ${ }^{4}$, Valery Paramonov ${ }^{4}$, \\ Ilia Slypko 4 (i) and Pavel Zabroda ${ }^{4}$ \\ 1 Department of Earth, Ocean and Atmospheric Sciences, University of British Columbia, 2207 Main Mall, \\ Vancouver, BC V6T 1Z4, Canada \\ 2 Institute for the Oceans and Fisheries, University of British Columbia, 2202 Main Mall, \\ Vancouver, BC V6T 1Z4, Canada \\ 3 Hakai Institute, P.O. Box 309, Heriot Bay, BC V0P 1H0, Canada \\ 4 Institute of Fisheries and Ecology of the Sea (IFES), 8 Konsulskaya Street, 71118 Berdyansk, Zaporozh'e \\ Region, Ukraine; lkpbikentnet@gmail.com (L.K.P.); krotanatoliy1@gmail.com (A.K.); \\ vparamonov@i.ua (V.P.); i.v.slipko@gmail.com (I.S.); pavlo.zabroda@ukr.net (P.Z.) \\ * Correspondence: epakhomov@eoas.ubc.ca
}

Received: 2 June 2020; Accepted: 30 June 2020; Published: 2 July 2020

\begin{abstract}
Preliminary results of the pilot study of the zooplankton in the region between the Ross and Scotia Seas from November 2017 to April 2018 are presented. In total, 53 zooplankton samples were collected in the top $100 \mathrm{~m}$ water layer using vertical tows of a $0.1 \mathrm{~m}^{2}$ Juday net from four Ukrainian longliners operating during the Antarctic toothfish fishery. Total zooplankton abundance ranged from 3 to 2836 ind $\mathrm{m}^{-3}$ with a global mean of $360 \pm 550( \pm 1 \mathrm{SD})$ ind $\mathrm{m}^{-3}$. The highest abundances were recorded at the northeastern Ross Sea. At those stations, small copepods (mainly Oithona spp., Oncaea spp., Ctenocalanus spp. and copepod nauplii) numerically dominated the samples. Total biomass ranged from 0.3 to $85 \mathrm{mg} \mathrm{DW} \mathrm{m}^{-3}$ with a mean of $10.9 \pm 14.5 \mathrm{mg} \mathrm{DW} \mathrm{m}^{-3}$. The highest biomasses were recorded at the eastern Ross Sea, where pelagic tunicates Salpa thompsoni, siphonophores and ctenophora Callianira sp. accounted for $>90 \%$ of total zooplankton biomass. At other stations, zooplankton biomass generally ranged from 5 to $20 \mathrm{mg} \mathrm{DW} \mathrm{m}^{-3}$ with no clear pattern in distribution. The community composition was driven by the sampling latitude and/or season rather than longitudinally. This pilot study emphasized the unique opportunity to investigate zooplankton dynamics in the regions traditionally not sampled during the oceanographic surveys. It also created unprecedented opportunities to increase the seasonal and geographical zooplankton sampling coverage using ships of opportunity at a fraction of a dedicated oceanographic survey costs. The potential of such surveys are enormous in both providing invaluable information, contributing to existing long-term databases and enhancing an international collaboration in the Southern Ocean, particularly in light of recent modeling initiatives of the whole Antarctic system undertaken by the Commission for the Conservation of Antarctic Marine Living Resources.
\end{abstract}

Keywords: zooplankton; Southern Ocean; abundance; biomass; distribution; community composition; ships of opportunity 


\section{Introduction}

Zooplankton play a pivotal role in the world's oceans, acting as a fundamental link between primary producers and top predators as well as commercially valuable fisheries [1-3]. Moreover, zooplankton contributes significantly to the biochemical cycling and export production affecting the cycling of carbon and other micro- and macronutrients in the ocean. It is a ubiquitous component of the biological pump mediating the organic matter removal from the surface to the deep ocean [4]. Zooplankton is a diverse group of organisms with crustacean plankton consistently dominating this group abundance and biomass [5]. Although zooplankton is extensively studied across marine environments, it is still poorly resolved in the biochemical and fisheries models. It is thus critical to gain a thorough understanding of the lower trophic level dynamics in pelagic ecosystems to be able to predict ecosystem responses under various climate change scenarios [6,7].

Since 1954, when A. de C. Baker [8] postulated the circum-Antarctic distribution of the Antarctic plankton, zooplankton has been repeatedly studied in the Atlantic (Antarctic Peninsula and Scotia Sea), Indian (Prydz Bay Region) and to a lesser extent in the Pacific (mainly the Ross Sea) sectors $[5,9,10]$. At the moment, we have a good understanding of species distribution patterns, biogeography, life cycles of major species, and long-term variability of the Antarctic pelagic ecosystems (see overview in $[5,11])$. Nevertheless, some regions of the Southern Ocean even today remain poorly sampled [12,13]. Historically, the area between the eastern parts of the Ross Sea and the Bellingshausen Sea in the Pacific Sector of the Southern Ocean receive little attention largely due to complicated logistics [12].

Recently, citizen science collections and observations, as well as ad-hoc sampling during commercial operations, have become a viable source of additional and often unique biological information at relatively low costs. While often such observations include only basic sampling, these collections provide important distributional data in areas that traditionally have been inadequately sampled, and improves seasonal and inter-annual coverage. During the 2017-18 season, the basic oceanographic data collections (as a pilot study) were carried out from long-line Ukrainian fishing boats during the licensed Antarctic toothfish fishery. This paper reports preliminary findings based on samples collected during austral summer in the poorly sampled coastal regions between the Ross and Bellingshausen seas as well as in the region east of the South Orkney Islands. The aims of this study were threefold: (a) to describe spatial and temporal zooplankton distribution; (b) to describe zooplankton composition; and (c) to investigate the development of the pelagic community in the top $100 \mathrm{~m}$ water layer.

\section{Materials and Methods}

Data on zooplankton composition, distribution and density were collected in the Pacific and Atlantic sectors of the Southern Ocean during five voyages onboard four Ukrainian longliners: SRTM (medium fishing trawler, freezer stern trawler) Calypso, Koreiz, Marigolds, and Simeiz, between November 17, 2017 and April 10, 2018 (Table 1, Figure 1). Zooplankton vertical tows were performed mainly during the daylight using a Juday net with a mouth area of $0.1 \mathrm{~m}^{2}$ and a mesh size of $100 \mu \mathrm{m}$. Nets were deployed generally to $100 \mathrm{~m}$ depth and retrieved at the speed of $\leq 1 \mathrm{~ms}^{-1}$. The net filtering surface to mouth area ratio was $\sim 5.5$ and volume filtered was calculated multiplying the distance net travelled (wire length) by the mouth area. The volume filtered ranged from 10 to $20 \mathrm{~m}^{3}$ (Table 1). Zooplankton was preserved in a $4 \%$ buffered formaldehyde-seawater solution. At some stations, sea surface temperature was recorded (Table 1). 
Table 1. List of stations conducted onboard Ukrainian long-liners during austral summer 2017-2018 in the Pacific and Atlantic sectors of the Southern Ocean. Abbreviations: K, Koreiz; M, Marigolds; C, Calypso; S, Simeiz; nr, not recorded.

\begin{tabular}{|c|c|c|c|c|c|c|c|}
\hline $\begin{array}{l}\text { Station } \\
\text { No. }\end{array}$ & Date & Time & $\begin{array}{l}\text { Latitude } \\
\text { (South) }\end{array}$ & $\begin{array}{l}\text { Longitude } \\
\text { (West) }\end{array}$ & $\begin{array}{l}\text { Depth Sampled } \\
(\mathrm{m})\end{array}$ & $\begin{array}{l}\text { Volume Filtered, } \\
\mathrm{m}^{3}\end{array}$ & $\underset{{ }^{\circ} \mathrm{C}}{\text { SurfaceT }}$ \\
\hline K1 & $11 / 17 / 2017$ & $17: 00$ & 68.187 & 112.308 & 103 & 11.0 & 0.0 \\
\hline K2 & $11 / 21 / 2017$ & $17: 40$ & 69.520 & 111.607 & 100 & 13.0 & -1.0 \\
\hline $\mathrm{K} 3$ & $11 / 26 / 2017$ & $17: 00$ & 70.672 & 111.422 & 104 & 10.5 & -1.7 \\
\hline K4 & $12 / 3 / 2017$ & $13: 50$ & 70.717 & 111.620 & 111 & 13.5 & -1.8 \\
\hline K5 & $12 / 9 / 2017$ & $17: 20$ & 70.917 & 113.965 & 125 & 13.0 & -1.7 \\
\hline K6 & $12 / 14 / 2017$ & $17: 20$ & 72.430 & 117.173 & 118 & 12.0 & -1.8 \\
\hline K7 & $12 / 16 / 2017$ & $12: 35$ & 73.932 & 117.172 & 141 & 20.0 & -1.6 \\
\hline K8 & $1 / 28 / 2018$ & $18: 30$ & 71.910 & 120.702 & 109 & 12.0 & -1.6 \\
\hline M1 & $11 / 28 / 2017$ & $11: 25$ & 65.503 & 177.599 & 101 & 10.5 & $\mathrm{nr}$ \\
\hline M2 & $1 / 16 / 2018$ & $10: 00$ & 72.088 & 176.695 & 100 & 11.0 & $\mathrm{nr}$ \\
\hline M3 & $1 / 16 / 2018$ & $17: 00$ & 72.872 & 179.983 & 100 & 11.0 & $\mathrm{nr}$ \\
\hline M4 & $1 / 17 / 2018$ & $0: 30$ & 73.177 & 177.594 & 100 & 11.6 & $\mathrm{nr}$ \\
\hline M5 & $1 / 18 / 2018$ & $9: 10$ & 75.008 & 163.665 & 100 & 10.0 & $\mathrm{nr}$ \\
\hline M6 & $1 / 18 / 2018$ & $18: 20$ & 75.034 & 157.864 & 100 & 10.5 & $\mathrm{nr}$ \\
\hline M7 & $1 / 19 / 2018$ & $10: 50$ & 74.638 & 147.513 & 100 & 11.0 & $\mathrm{nr}$ \\
\hline M8 & $1 / 21 / 2018$ & $20: 10$ & 74.068 & 135.990 & 100 & 10.5 & $\mathrm{nr}$ \\
\hline M9 & $1 / 24 / 2018$ & $19: 50$ & 74.068 & 131.488 & 100 & 10.5 & $\mathrm{nr}$ \\
\hline $\mathrm{C} 1$ & $12 / 12 / 2017$ & $22: 45$ & 65.380 & 178.397 & 100 & 11.6 & $\mathrm{nr}$ \\
\hline $\mathrm{C} 2$ & $1 / 14 / 2018$ & $16: 20$ & 72.648 & 176.247 & 100 & 10.2 & $\mathrm{nr}$ \\
\hline $\mathrm{C} 3$ & $1 / 18 / 2018$ & $9: 40$ & 74.142 & 139.456 & 100 & 11.6 & $\mathrm{nr}$ \\
\hline S1 & $11 / 29 / 2017$ & $18: 00$ & 64.573 & 171.133 & 113 & 12.0 & $\mathrm{nr}$ \\
\hline S2 & $12 / 1 / 2017$ & $15: 00$ & 64.593 & 171.072 & 113 & 13.0 & $\mathrm{nr}$ \\
\hline S3 & $1 / 11 / 2018$ & $21: 35$ & 74.112 & 136.119 & 118 & 13.0 & $\mathrm{nr}$ \\
\hline $\mathrm{S} 4$ & $1 / 28 / 2018$ & $1: 40$ & 72.583 & 121.128 & 99 & 14.0 & $\mathrm{nr}$ \\
\hline S_1 & $2 / 27 / 2018$ & $10: 00$ & 61.905 & 37.583 & 118 & 12.0 & 0.2 \\
\hline S_2 & $2 / 27 / 2018$ & $14: 30$ & 62.000 & 36.833 & 122 & 13.0 & 0.0 \\
\hline S_3 & $2 / 27 / 2018$ & $15: 30$ & 61.999 & 36.502 & 121 & 14.0 & 0.0 \\
\hline S_4 & $2 / 27 / 2018$ & $19: 30$ & 61.583 & 35.667 & 122 & 13.0 & 0.0 \\
\hline S_5 & $2 / 27 / 2018$ & $21: 30$ & 61.430 & 34.247 & 114 & 14.0 & 0.0 \\
\hline S_6 & $2 / 27 / 2018$ & 23:00 & 61.350 & 34.673 & 112 & 13.0 & 0.0 \\
\hline S_7 & $2 / 28 / 2018$ & $9: 15$ & 60.932 & 35.067 & 121 & 14.0 & 0.7 \\
\hline S_8 & $2 / 28 / 2018$ & $11: 15$ & 60.833 & 36.167 & 118 & 12.0 & 1.5 \\
\hline S_9 & $2 / 28 / 2018$ & $13: 45$ & 61.169 & 36.180 & 113 & 12.0 & 1.4 \\
\hline S_10 & $2 / 28 / 2018$ & $15: 30$ & 61.257 & 36.669 & 113 & 12.0 & 1.6 \\
\hline S_11 & $2 / 28 / 2018$ & $18: 00$ & 61.333 & 37.250 & 113 & 12.5 & 1.6 \\
\hline S_12 & $2 / 28 / 2018$ & $20: 30$ & 61.500 & 36.833 & 104 & 12.0 & 1.5 \\
\hline S_13 & $2 / 28 / 2018$ & $21: 30$ & 61.500 & 36.417 & 98 & 12.0 & 1.5 \\
\hline S_14 & $3 / 2 / 2018$ & $12: 40$ & 61.667 & 39.167 & 109 & 11.0 & 1.4 \\
\hline S_15 & $3 / 2 / 2018$ & $14: 00$ & 61.750 & 38.667 & 109 & 12.0 & 1.4 \\
\hline S_16 & $3 / 2 / 2018$ & $16: 20$ & 61.998 & 39.168 & 106 & 11.0 & 1.4 \\
\hline S_17 & $3 / 2 / 2018$ & $18: 00$ & 61.998 & 38.667 & 103 & 11.0 & 1.4 \\
\hline S_18 & $3 / 2 / 2018$ & $21: 10$ & 62.017 & 40.634 & 103 & 11.0 & 1.4 \\
\hline S_19 & $3 / 31 / 2018$ & $17: 30$ & 60.002 & 34.007 & 116 & 12.0 & 0.7 \\
\hline S_20 & $3 / 31 / 2018$ & $19: 30$ & 60.333 & 34.417 & 108 & 11.0 & 0.7 \\
\hline S_21 & $3 / 31 / 2018$ & $21: 25$ & 60.658 & 34.678 & 91 & 10.5 & 0.7 \\
\hline S_22 & $4 / 2 / 2018$ & $21: 10$ & 60.583 & 35.333 & 100 & 11.0 & 0.8 \\
\hline S_23 & $4 / 8 / 2018$ & $5: 30$ & 59.592 & 35.422 & 100 & 11.0 & 0.9 \\
\hline S_24 & $4 / 8 / 2018$ & $9: 20$ & 59.672 & 36.167 & 104 & 12.0 & 1.0 \\
\hline S_25 & $4 / 10 / 2018$ & $7: 30$ & 61.250 & 37.833 & 113 & 12.0 & 1.2 \\
\hline S_26 & $4 / 10 / 2018$ & $13: 20$ & 60.916 & 38.298 & 108 & 11.0 & 1.2 \\
\hline S_27 & $4 / 10 / 2018$ & $15: 40$ & 60.666 & 37.833 & 106 & 11.0 & 1.3 \\
\hline S_28 & $4 / 10 / 2018$ & $20: 20$ & 60.255 & 36.752 & 100 & 11.0 & 1.4 \\
\hline S_29 & $4 / 10 / 2018$ & $21: 40$ & 60.207 & 37.167 & 94 & 11.5 & 1.4 \\
\hline
\end{tabular}




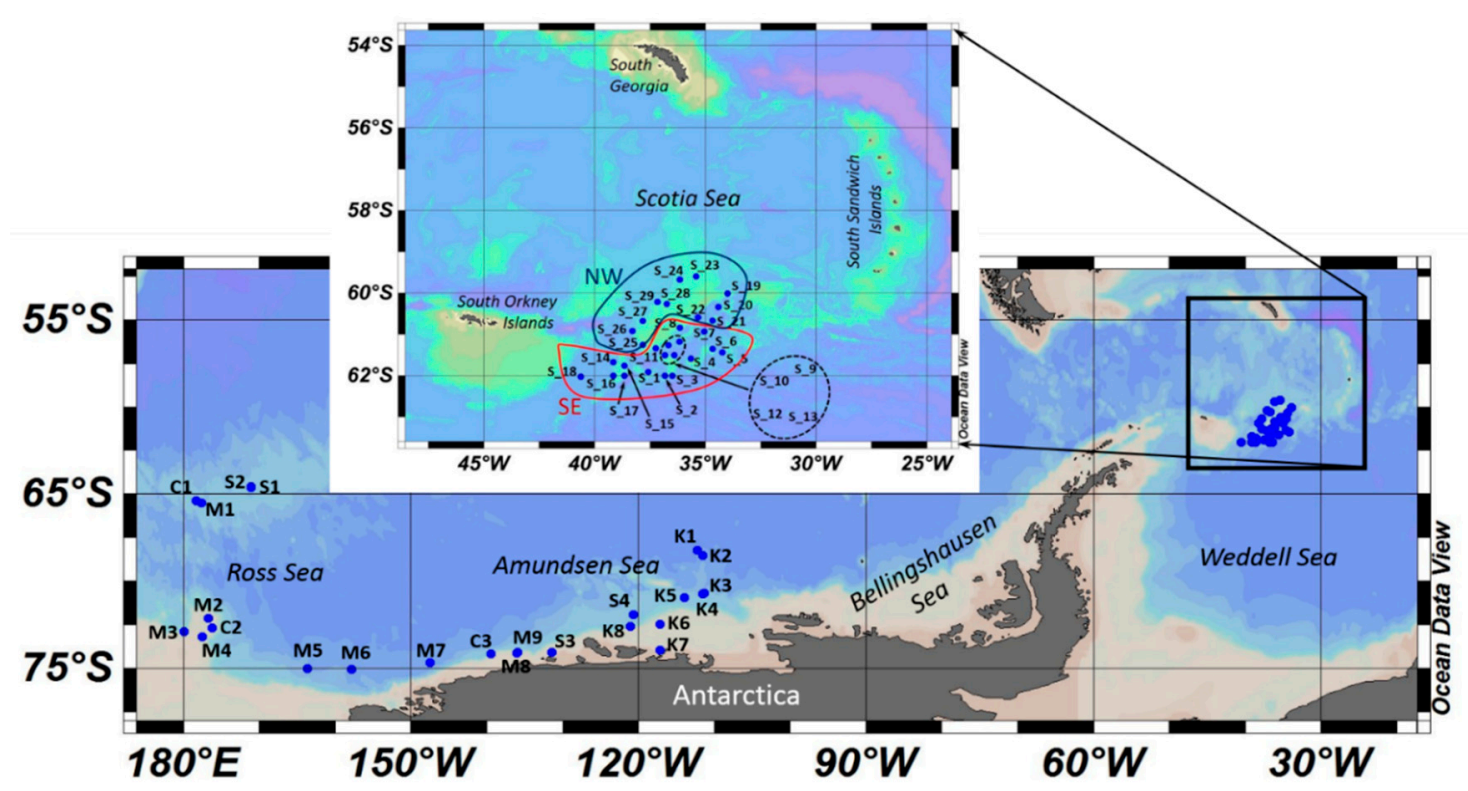

Figure 1. Sample collections carried out from Ukrainian long-liners during austral summer 2017-2018 in the Pacific and Atlantic sectors of the Southern Ocean. In the insert, SIMEIZ collections, NW, northwestern South Orkney Islands (27 February to 3 March, 2018); SE, southeastern South Orkney Islands (31 March to 10 April, 2018). Station abbreviations: K, Koreiz collections (17 November, 2017 to 28 January, 2018); M, Marigolds collections (28 November, 2017 to 24 January, 2018); C, Calypso collections (12 December, 2017 to 18 January, 2018); S, Simeiz collections (29 November, 2017 to 28 January, 2018).

Zooplankton taxa were identified to the lowest taxonomic level when possible. For four major calanoid copepod species, Metrida gerlachei, Calanus propinquus, Calanoides acutus, and Rhincalanus gigas, all copepodite stages were identified. In the lab, the whole sample was initially processed by identifying, measuring, and counting all large $(>10 \mathrm{~mm})$ and rare (clearly visible $<10 \mathrm{~mm}$ ) organisms. The smallmouth area and fine mesh size likely significantly under-sampled large $(>10 \mathrm{~mm})$ organisms and their density estimates should be considered with caution. The remaining sample was processed either entirely if there where $<200$ individuals or sub-sampled (1/2 to $1 / 8)$ using a plankton splitter till approximately 200-300 individuals remained. This was used to quantify all organisms with the exception of small calanoids (Ctenocalanus and Clausocalanus), Oithona spp., Oncaea spp., Microsetella spp., copepod nauplii and crustacean eggs, which were counted in $5 \mathrm{~mL}$ sub-sample constituting 1/20 or $1 / 30$ of the total sample. Abundance was calculated by dividing the count data by the proportion of the sample processed and then dividing the total count by the volume filtered and expressed as ind $\mathrm{m}^{-3}$. Biomass was calculated using conversions of zooplankton species and stage data to $\mathrm{mg}$ dry weight (DW) using [14] multiplied by the abundance data and expressed as $\mathrm{mg} \mathrm{DW}^{-3}$.

To compare plankton communities, a non-metric cluster and MDS analyses were performed using the Plymouth routines in multivariate ecological research (PRIMER 6; [15]) computer package according to the procedure described by Field et al. [16]. Species abundance data were $\log 10(x+1)$ transformed, and a station similarity matrix generated using the Bray-Curtis metric. Cluster analysis was then applied using group average sorting. To test for significant numerical differences between identified clusters and seasons, ANOVA was conducted on log-transformed abundance and biomass data [17].

MDS was performed on the similarity matrix. A SIMPROF test was conducted $(\alpha=0.01)$ to determine statistical significance between clusters [15]. 


\section{Results}

\subsection{Spatial Patterns in the Zooplankton Density and Composition}

Total zooplankton abundance ranged from 2.9 to 2836 ind $\mathrm{m}^{-3}$ with a global mean of $360 \pm 550$ $( \pm 1 \mathrm{SD})$ ind $\mathrm{m}^{-3}$. The highest abundances were recorded at the northeastern Ross Sea (Figure 2A). At those stations, small copepods (mainly Oithona spp., Oncaea spp., Ctenocalanus spp. and copepod nauplii) numerically dominated samples (Figure 3). At the remaining stations, zooplankton abundances usually varied between 100 and 500 ind $\mathrm{m}^{-3}$ with the tendency to increase from the west to the east (Figures 2A and 3). With the exception of a few stations, small copepods accounted for $>>60 \%$ of total abundance (Figure 3). The second most abundant group comprised of large calanoid copepods contributing from 10 to $40 \%$ of the total abundance. There was a tendency of increasing large copepod contributions at the northerly stations occupied in the Ross and the Scotia seas (Figure 3). It was also noted that the highest contributions and densities of small copepods coincided with the stations characterized by high phytoplankton concentrations. Phytoplankton concentration was not measured and inferred from phytoplankton dominating in zooplankton samples. The third-largest zooplankton group was composed of euphausiids accounting for 5 to $60 \%$ of total abundance. At the western stations, it was mostly presented by Thysanoessa macrura, while in the Scotia Sea, larval stages (mostly calyptopis 1) of Euphausia superba dominated reaching densities of 304 ind $\mathrm{m}^{-3}$ (Sta. S_20; Figure 3). Other groups combined seldom contributed more than $5 \%$ to the total zooplankton abundance.
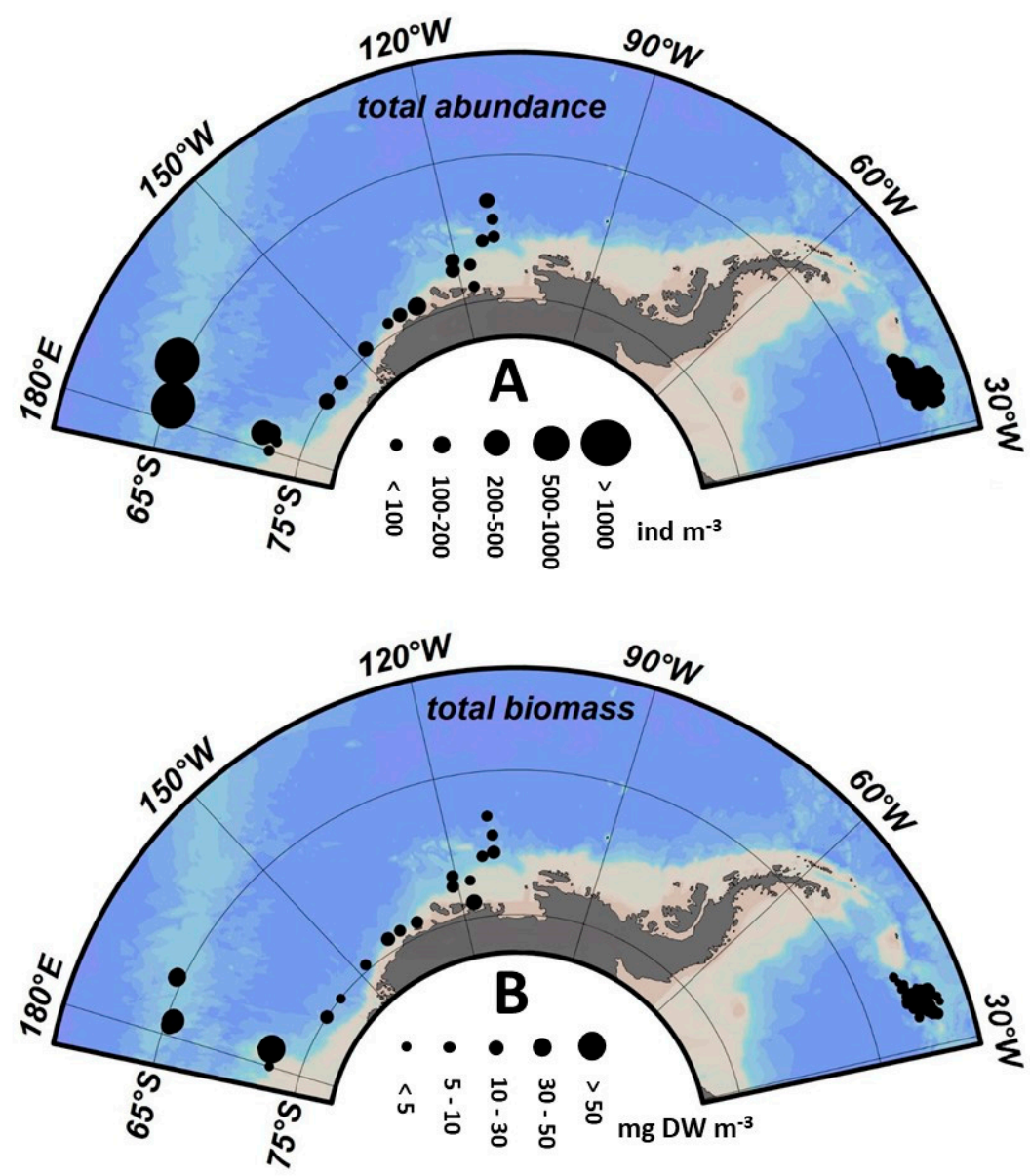

Figure 2. Spatial distribution of total zooplankton abundance ((A), ind $\left.\mathrm{m}^{-3}\right)$ and biomass ((B), $\left.\mathrm{mg} \mathrm{DW} \mathrm{m}^{-3}\right)$ in the upper $100 \mathrm{~m}$ layer during austral summer 2017-2018 in the Pacific and Atlantic sectors of the Southern Ocean. 

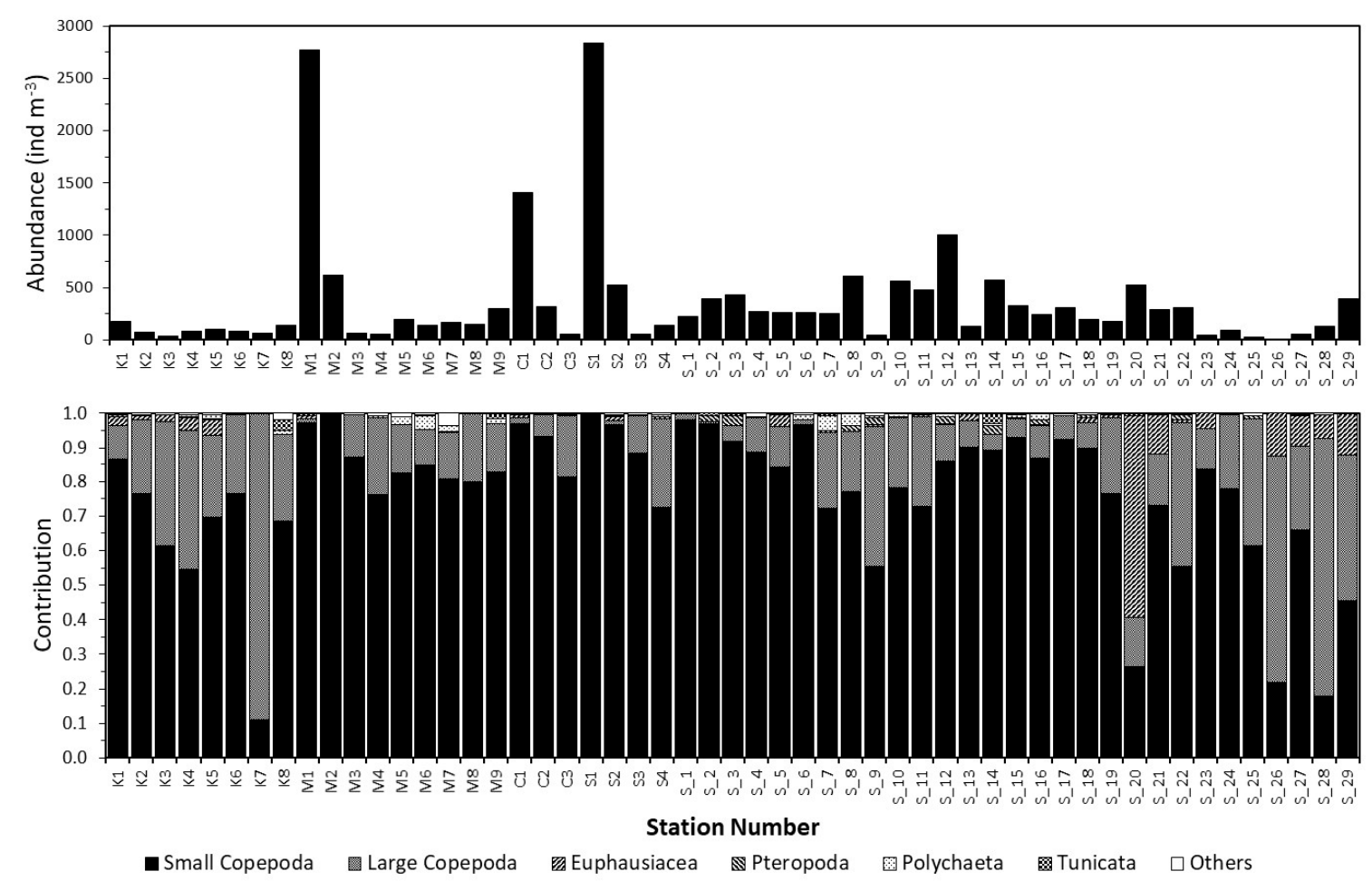

Figure 3. Zooplankton total abundance (upper panel) and contribution of major taxonomic groups (lower panel) in the Pacific and Atlantic sector of the Southern Ocean during austral summer 2017-18.

Total biomass ranged from 0.3 to $85 \mathrm{mg} \mathrm{DW} \mathrm{m}^{-3}$ with a mean of $10.9 \pm 14.5 \mathrm{mg} \mathrm{DW} \mathrm{m}^{-3}$. The highest biomasses were recorded at two stations (M1 and C2) of the eastern Ross Sea (Figure 2B). The first station was characterized by generally high concentrations of small and large copepods as well as pelagic tunicates, Salpa thompsoni, and siphonophores, while on the station C2, ctenophora Callianira sp. accounted for $>90 \%$ of total zooplankton biomass (Figure 4). At other stations, zooplankton biomass generally ranged from 5 to $20 \mathrm{mg} \mathrm{DW} \mathrm{m}^{-3}$ with no clear pattern in distribution (Figures 2B and 4). Generally, at the stations with biomass levels $<5 \mathrm{mg} \mathrm{DW} \mathrm{m}^{-3}$, small copepods accounted for $>60 \%$ of total biomass, while in the majority of stations, large calanoid copepods composed the largest proportion (range 3 to $99 \%$ ) of total biomass (Figure 4). At some stations, other groups contributed significantly to total zooplankton biomass: e.g., euphausiids, up to $46 \%$ (Sta. S_23); amphipods, mainly Themisto gaudichaudii,_-up to $28 \%$ (Sta. S_11); jellies—up to $54 \%$ (Sta. C3); chaetognaths, up to $6 \%$ (Sta. S_14) (Figure 4). A similar to abundance tendency of increasing euphausiid contributions from west to east was observed (Figure 4). Other groups combined generally contributed $<<20 \%$ to the total zooplankton biomass.

\subsection{Dynamics of the Copepod Community}

With several exceptions, total copepod density ranged between 100 and 300 ind $\mathrm{m}^{-3}$ and was generally higher in the Scotia Sea compared to the Ross Sea and Amundsen Sea stations (Figure 5). Nevertheless, three stations with the highest $\left(>1000\right.$ ind $\left.\mathrm{m}^{-3}\right)$ copepod abundances were observed in the north-east Ross Sea. At all stations, small copepods dominated the samples: Oithona spp at Sta. S1, Oithona spp., Ctenocalanus spp., and copepod nauplii at Sta. M1; and with the addition of Oncaea spp. at Sta. C1 (Figure 5). Overall, Oithona spp. and copepod nauplii were prominent components of the copepod community (Figure 5). While Oncaea spp. contributed substantially in the southern stations of both Ross and Amundsen Seas, the north-western part of the Scotia Sea survey was nearly devoid of this species (Figure 5). Instead, the contribution of larger calanoids, e.g., C. propinquus, C. acutus, and M. gerlachei was significant. 

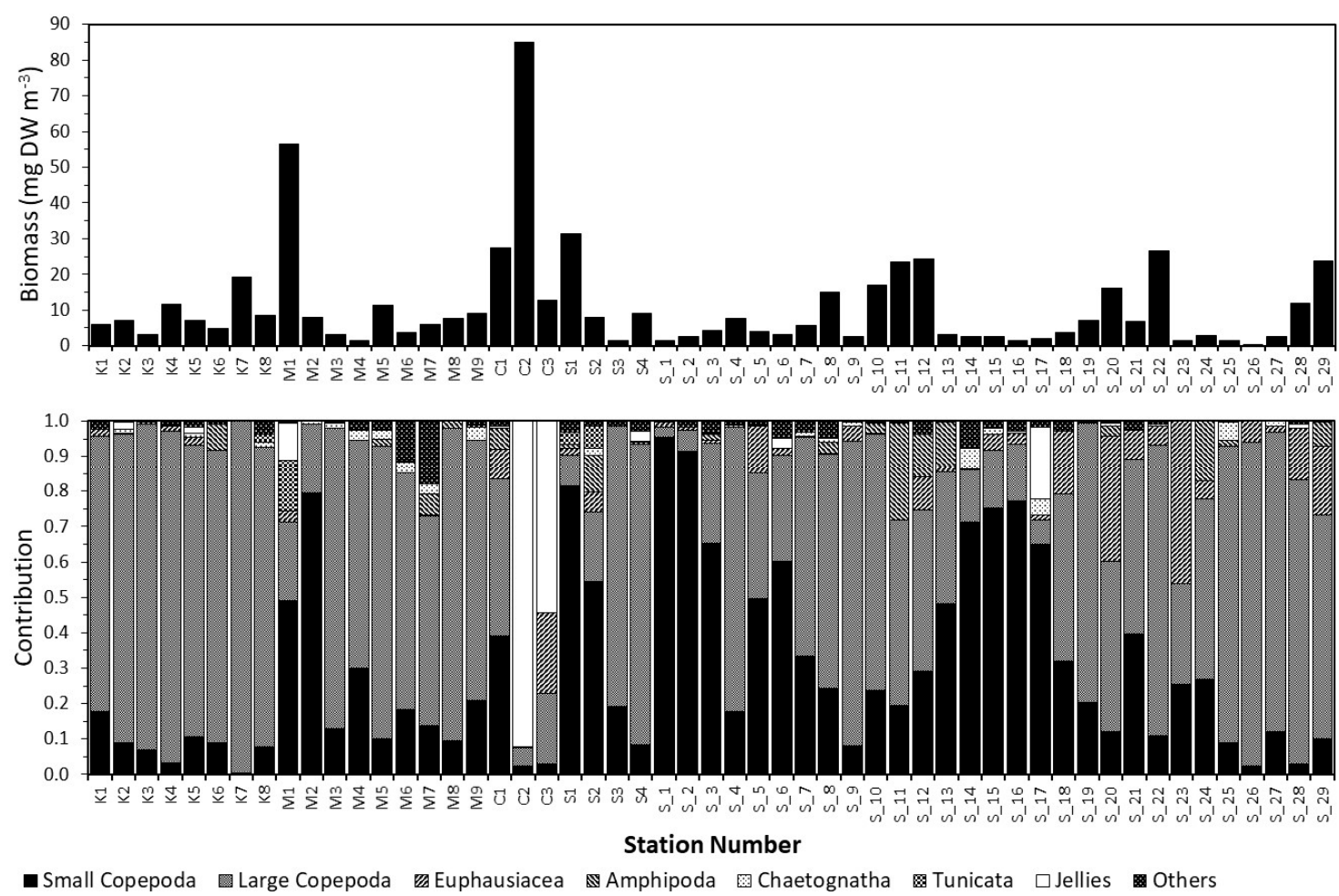

Figure 4. Zooplankton total biomass (upper panel) and contribution of major taxonomic groups (lower panel) in the Pacific and Atlantic sector of the Southern Ocean during austral summer 2017-18.
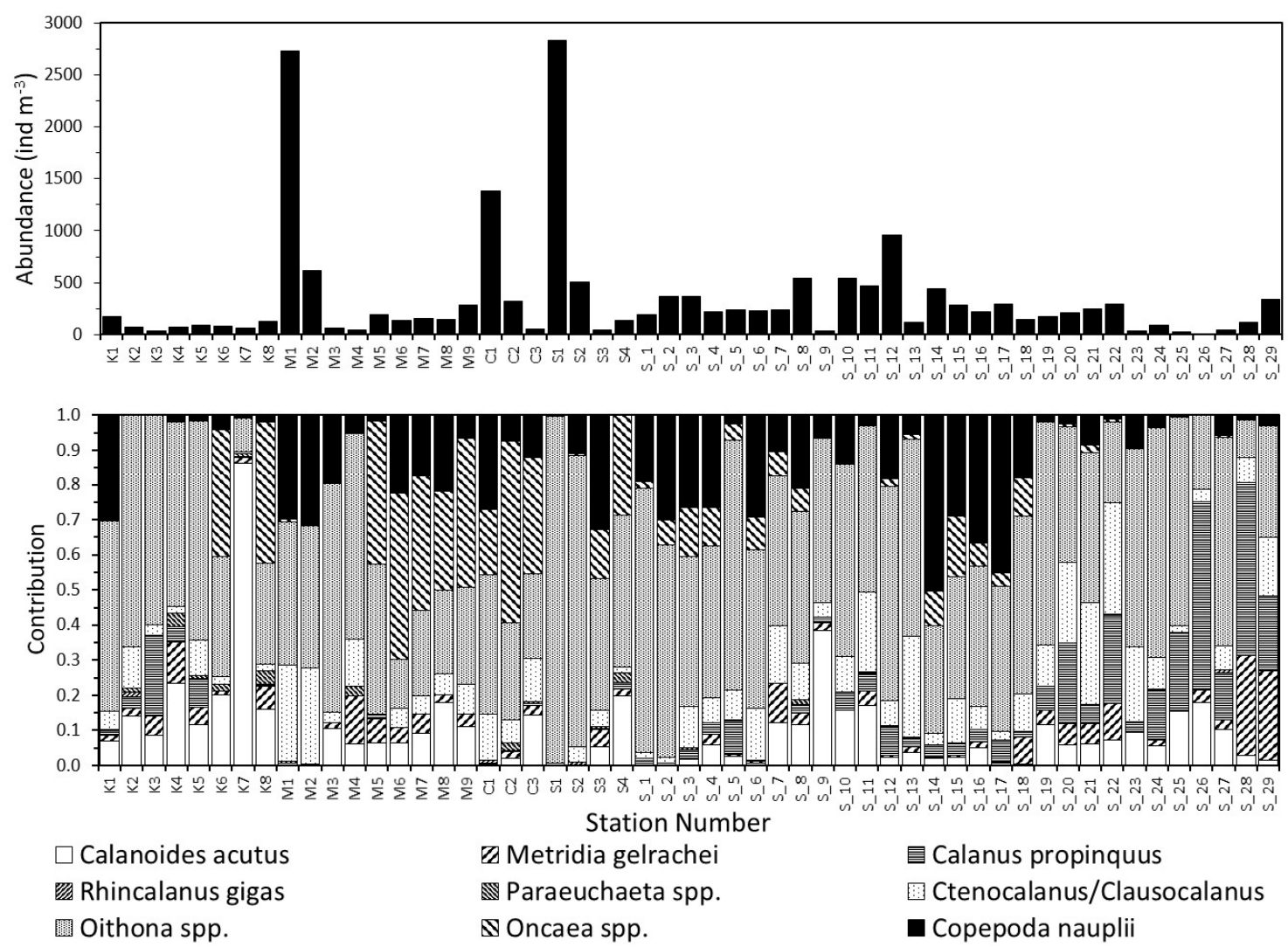

Figure 5. Copepod community total abundance (upper panel) and species contributions (lower panel) in the Pacific and Atlantic sector of the Southern Ocean during austral summer 2017-18. 


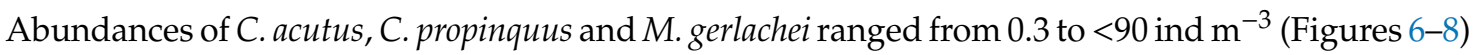

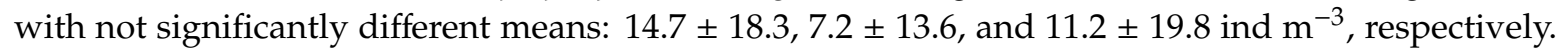
Both C. propinquus and M. gerlachei were mostly caught in the Scotia Sea (Figures 7 and 8), while C. acutus was found across all regions (Figure 6). It was similar for all species as they all followed a seasonal progression in the development composition. Generally, copepodites 4-5 and adult individuals dominated at the Scotia and Ross Sea stations, with the exception of the north-east Ross Sea region (Figures 6-8). Developing populations of all copepods (copepodites 1 to 4 dominated) were observed in the Scotia Sea during the survey conducted in February to March 2018 (Figures 6-8).
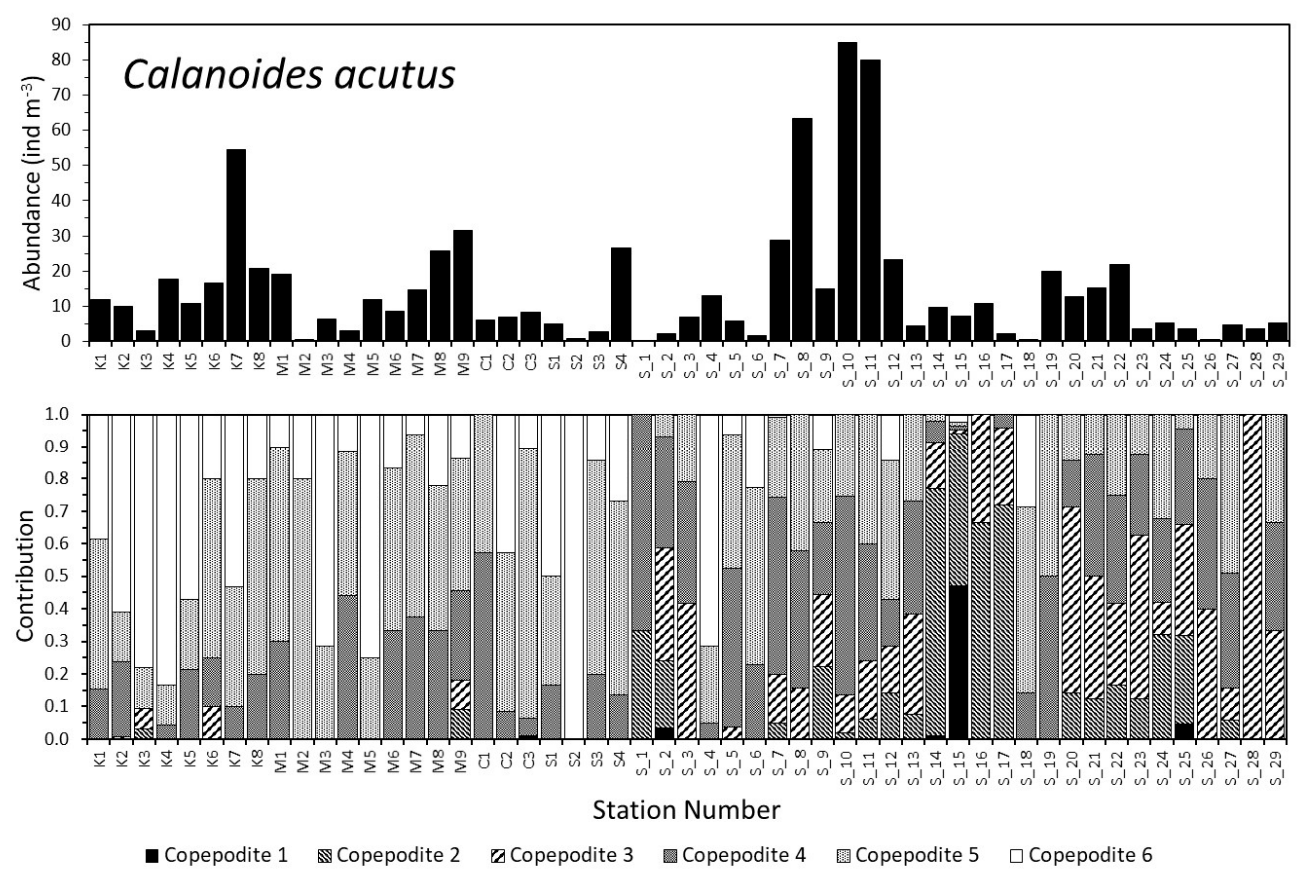

Figure 6. Calanoides acutus abundance (upper panel) and developmental stage composition (lower panel) in the Pacific and Atlantic sector of the Southern Ocean during austral summer 2017-18.
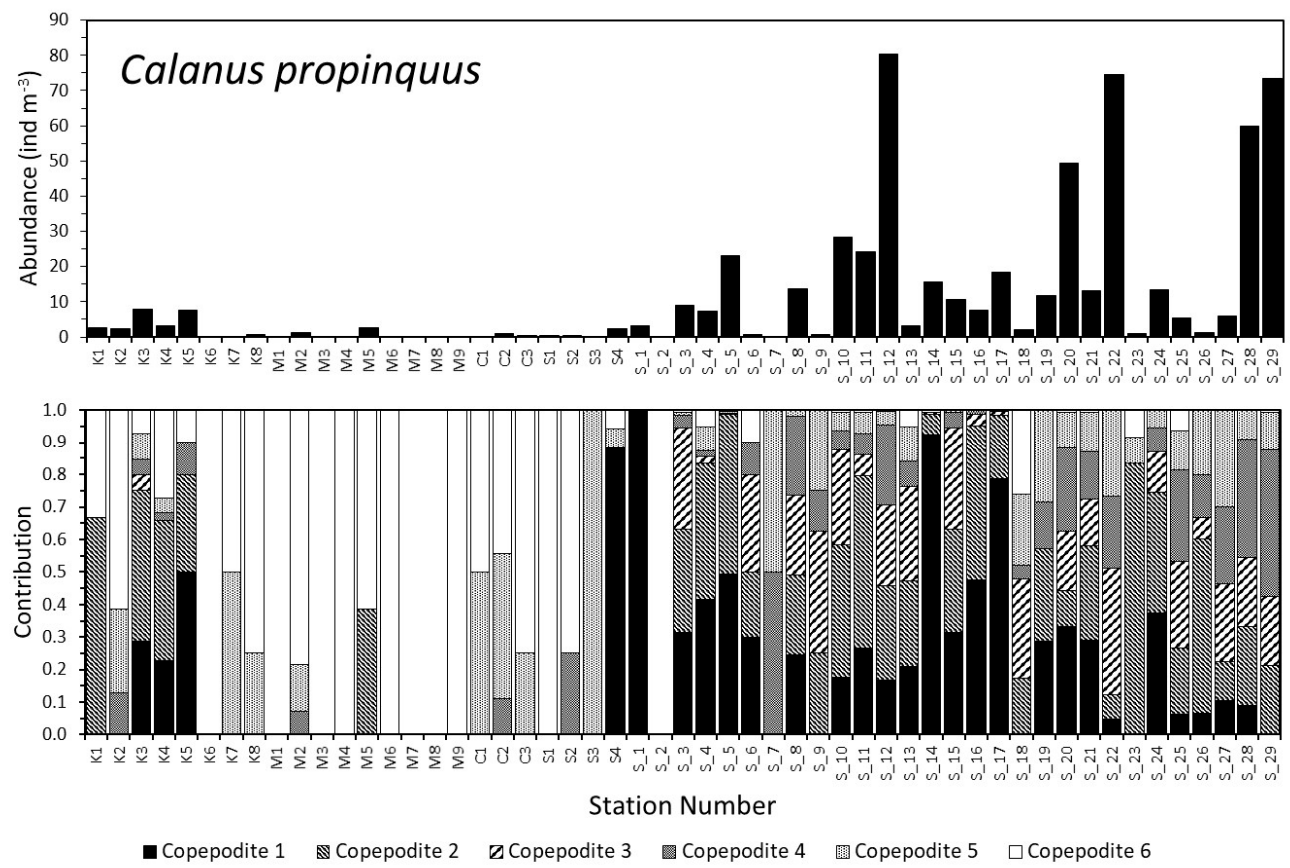

Figure 7. Calanus propinquus abundance (upper panel) and developmental stage composition (lower panel) in the Pacific and Atlantic sector of the Southern Ocean during austral summer 2017-18. 

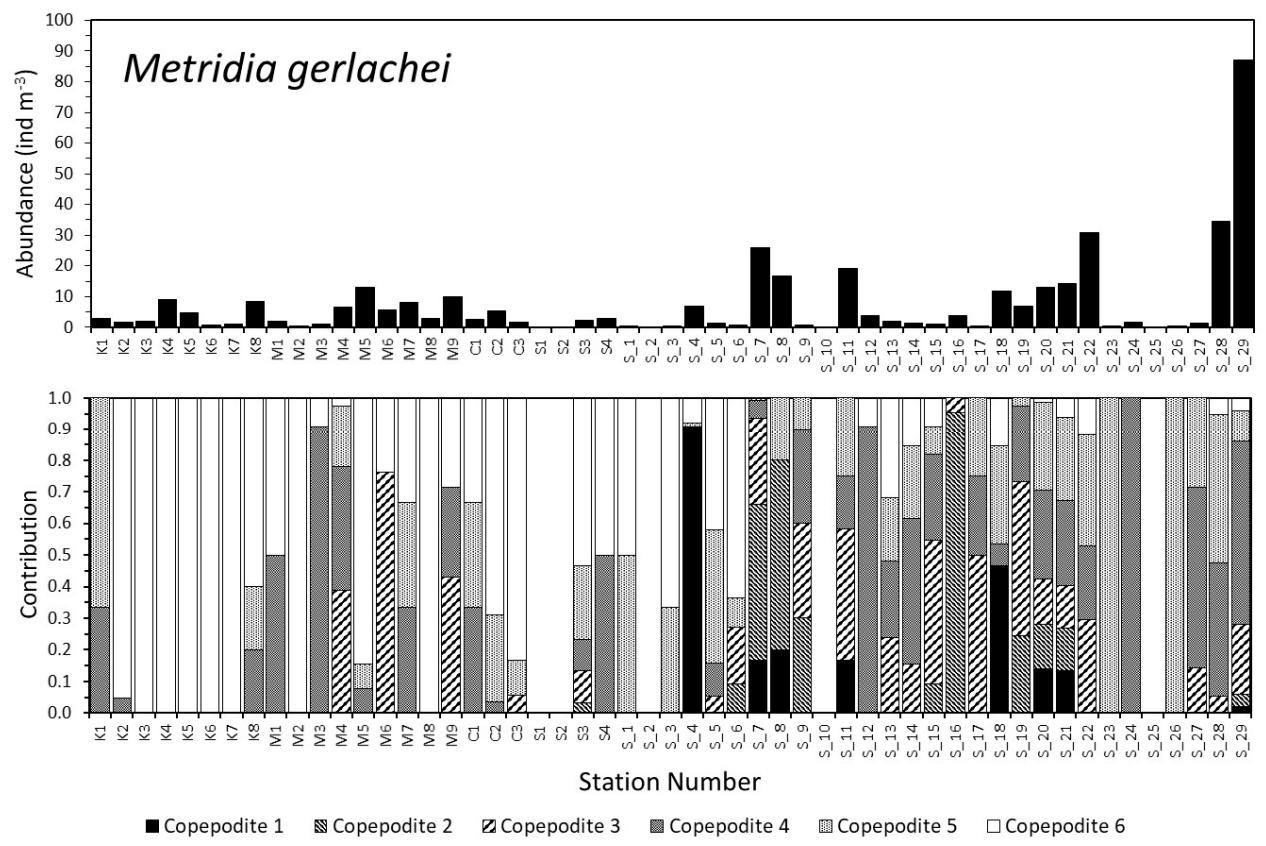

Figure 8. Metridia gerlachei abundance (upper panel) and developmental stage composition (lower panel) in the Pacific and Atlantic sector of the Southern Ocean during austral summer 2017-18.

Although seasonal patterns could only be studied across regions, it was possible to suggest that the highest, albeit highly variable, zooplankton abundance and biomass were observed in November (Figure 9). The overall pattern of seasonal densities showed a progressive decline from November to March despite the fact that differences between mean values were not significant (ANOVA, $p>0.05$ ) (Figure 9).
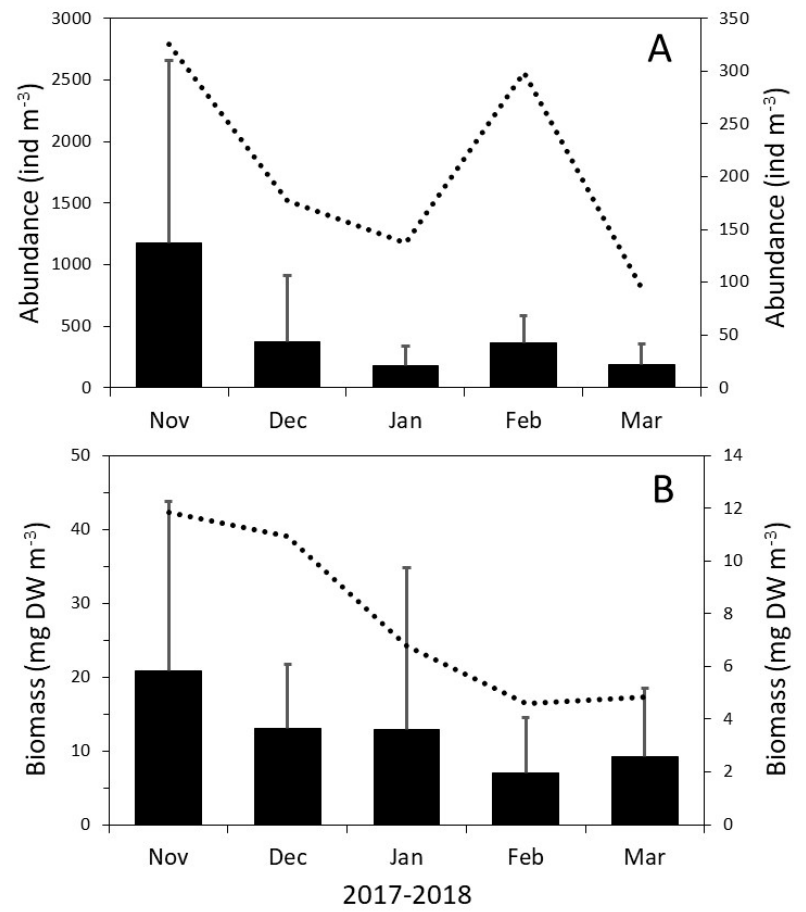

Figure 9. Seasonal dynamics of zooplankton abundance (A) and biomass (B) in the upper $100 \mathrm{~m}$ layer during austral summer 2017-2018 in the Pacific and Atlantic sectors of the Southern Ocean. Bars with 1SD illustrate the arithmetic mean densities (left axis), the dotted line shows the geometric mean (right axis). 


\subsection{Community Composition Dynamics}

Cluster analysis revealed five major station groupings and two outliers (Figure 10). Clusters 1 and 2, which were separated from each other at $\sim 67 \%$ similarity, broadly corresponded to north western and south eastern Scotia Sea stations (Figures 1 and $10 \mathrm{~A}$ ). Cluster 4 was separated at $\sim 50 \%$ similarity and was composed of stations conducted in the northeast of the Ross Sea, while clusters 3 and 5, separated at $~ 55 \%$ similarity, included a mixture of the stations of all Ross, Amundsen and Scotia seas (Figures 1 and 10A). These clusters were also visible using the MDS analysis (Figure 10B). The outliers were characterized by either very low zooplankton density or low diversity.

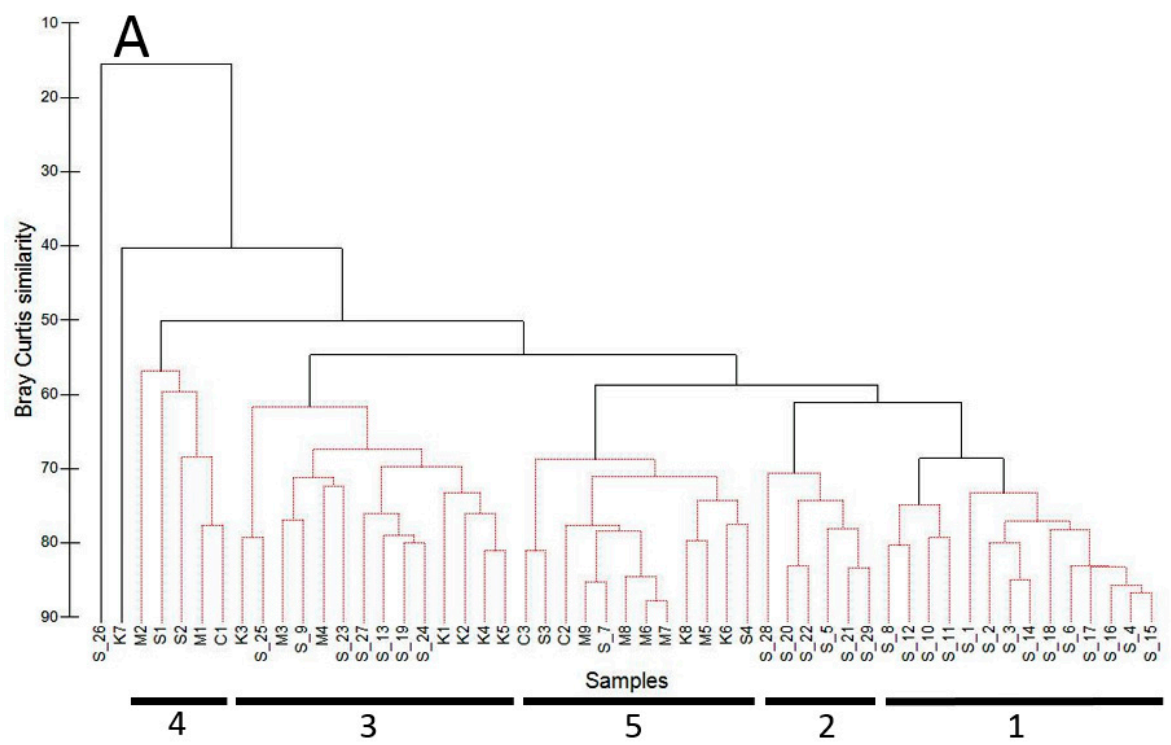

\section{B}

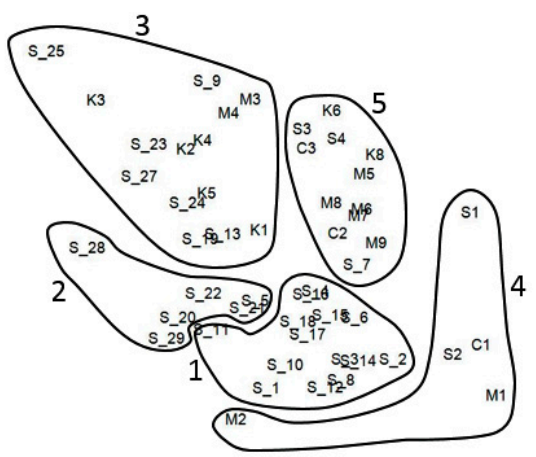

Figure 10. Cluster (A) and MDS (B) analyses of zooplankton collections (by species abundance only) in the southern parts of the Pacific and Atlantic sectors of the Southern Ocean during austral summer 2017-18.

The total zooplankton abundance of cluster 1 was the highest and was significantly higher (ANOVA, $p<0.05$ ) than total abundance in clusters 2 to 4 , while clusters 2 to 5 abundances did not differ significantly (ANOVA, $p>0.05$ ) (Figure 11; Table 2). Although a similar pattern was observed for total biomass, biomasses were not significantly different among clusters (Figure 11, Table 2). 

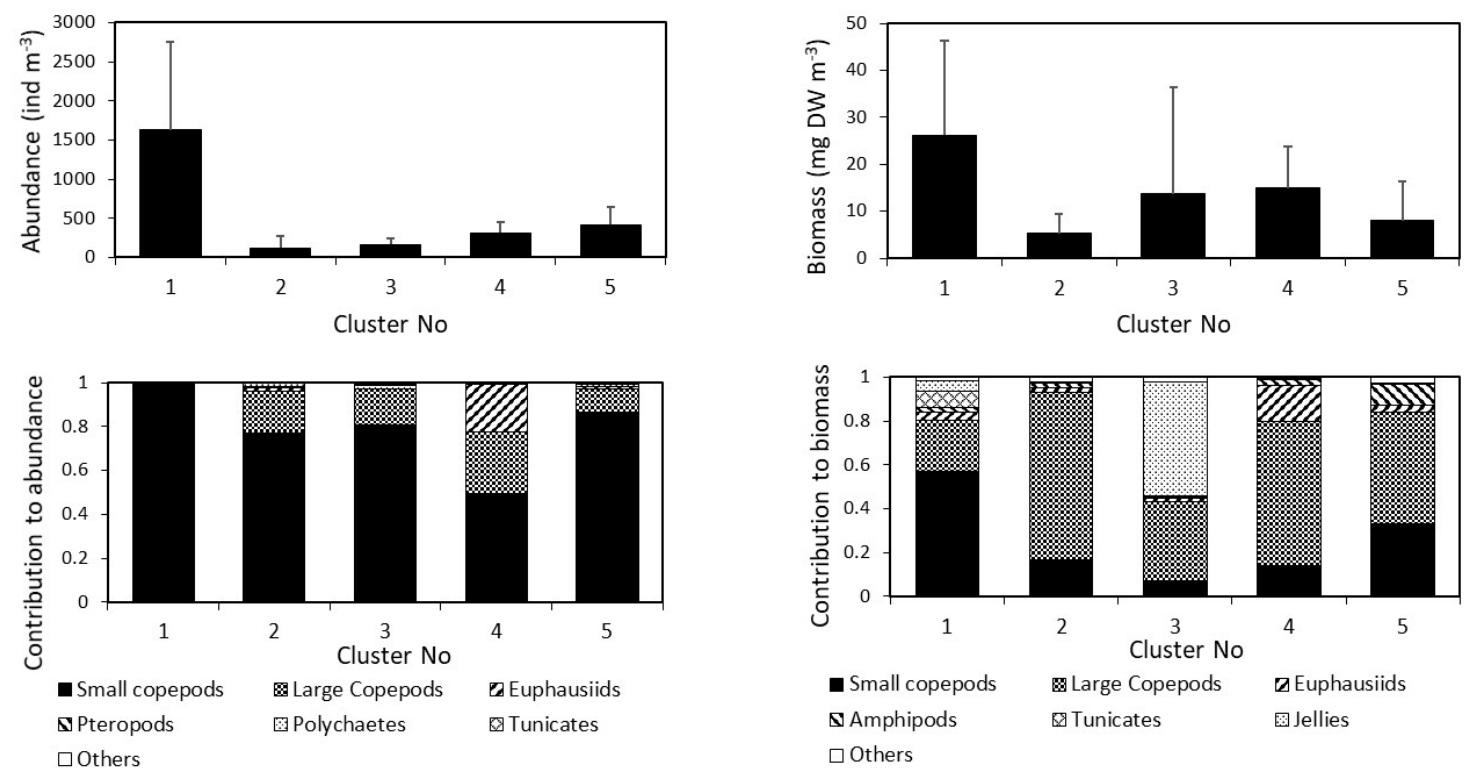

Figure 11. Zooplankton total abundance (left panels) and biomass (right panels), as well as taxonomic group composition (bottom panels, respectively), in the Pacific and Atlantic sector of the Southern Ocean during austral summer 2017-18 in clusters identified in Figure 10A.

Table 2. Species composition and densities of zooplankton communities identified using the cluster analysis presented in Figure 10A. Total abundance (A) and biomass (B) are expressed as ind $\mathrm{m}^{-3}$ and $\mathrm{mg} \mathrm{DW} \mathrm{m}^{-3}$, while numbers in columns are proportions.

\begin{tabular}{|c|c|c|c|c|c|c|c|c|c|c|}
\hline \multirow{2}{*}{ Species } & \multicolumn{2}{|c|}{ Cluster 1} & \multicolumn{2}{|c|}{ Cluster 2} & \multicolumn{2}{|c|}{ Cluster 3} & \multicolumn{2}{|c|}{ Cluster 4} & \multicolumn{2}{|c|}{ Cluster 5} \\
\hline & A & B & A & B & A & B & A & B & A & B \\
\hline Calanoides acutus & 0.4 & 5.3 & 9.9 & 50.4 & 10.3 & 27.6 & 3.4 & 6.8 & 5.2 & 36.6 \\
\hline Metridia gerlachei & 0.1 & 0.4 & 3.3 & 6.3 & 4.4 & 5.1 & 9.5 & 6.1 & 1.1 & 1.4 \\
\hline Pleuromamma spp. & 0 & 0 & 0.4 & $<0.1$ & 0 & 0 & $<0.1$ & $<0.1$ & 0.1 & $<0.1$ \\
\hline Ctenocalanus/Clausocalanus & 13.6 & 20.2 & 10 & 5.5 & 6.2 & 1.8 & 15.9 & 8.1 & 8.2 & 10.3 \\
\hline Paraeuchaeta spp. & 0 & 0 & 0.7 & 0.5 & 0.9 & 0.5 & 0.1 & 1.7 & 0.1 & 0.1 \\
\hline Euchirella rostromagna & 0 & 0 & 0 & 0 & 0 & 0 & $<0.1$ & 0.1 & $<0.1$ & 0.1 \\
\hline Calanus propinquus & 0 & 1.5 & 4.6 & 18.8 & 0.4 & 2.5 & 15.4 & 51.3 & 3.8 & 12.4 \\
\hline Calanus simillimus & 0 & 1.8 & 0 & 0 & 0 & 0 & 0 & 0 & 0 & 0 \\
\hline Rhincalanus gigas & 0.4 & 14.2 & 0.1 & 0.9 & $<0.1$ & 0.2 & $<0.1$ & 0.1 & 0.1 & 0.7 \\
\hline Oithona spp. & 62.4 & 34.9 & 50.9 & 10.6 & 30.2 & 3.2 & 28.9 & 5.5 & 43.9 & 20.8 \\
\hline Oncaea spp. & 3.5 & 1.1 & 2.3 & 0.3 & 35.1 & 2.1 & 1.1 & 0.1 & 5.5 & 1.4 \\
\hline Microsetella spp. & 1.4 & 0.5 & 0.1 & $<0.1$ & 0 & 0 & 0 & 0 & 0 & 0 \\
\hline Thysanoessa macrura & 0.6 & 4.1 & 0.9 & 1.9 & $<0.1$ & 0.1 & 0.5 & 5.7 & 0.1 & 2.2 \\
\hline Euphausia crystallorophias & 0 & 0 & 0 & 0 & $<0.1$ & 1.8 & 0 & 0 & 0 & 0 \\
\hline Euphausia superba & 0 & 0 & 0.5 & 0.1 & 0 & 0 & 21 & 10.8 & $<0.1$ & 0.8 \\
\hline Crustacea eggs & $<0.1$ & $<0.1$ & 1.9 & $<0.1$ & $<0.1$ & $<0.1$ & 1 & $<0.1$ & 7.1 & $<0.1$ \\
\hline Copepoda egg clusters & 0 & 0 & 0 & 0 & $<0.1$ & $<0.1$ & 0 & 0 & $<0.1$ & $<0.1$ \\
\hline Copepoda nauplii & 17.3 & 0.2 & 11.9 & 0.1 & 9.5 & 0 & 2.5 & $<0.1$ & 22 & 0.2 \\
\hline Themisto gaudichaudii & 0 & 0 & $<0.1$ & 1.8 & 0 & 0 & $<0.1$ & 2.3 & $<0.1$ & 9.4 \\
\hline Vibilia antarctica & $<0.1$ & 2 & 0 & 0 & 0 & 0 & 0 & 0 & 0 & 0 \\
\hline Primno macropa & $<0.1$ & $<0.1$ & $<0.1$ & $<0.1$ & 0 & 0 & 0 & 0 & $<0.1$ & 0.1 \\
\hline Hyperiella dilatata & 0 & 0.1 & 0 & 0 & $<0.1$ & 0.4 & 0 & 0 & 0 & 0 \\
\hline Eusirus sp. & 0 & 0 & 0 & 0 & $<0.1$ & 0.2 & 0 & 0 & 0 & 0 \\
\hline Nematocarcinus spp. & 0 & 0 & $<0.1$ & $<0.1$ & 0 & 0 & 0 & 0 & 0 & 0 \\
\hline Ostracoda & $<0.1$ & 0.2 & $<0.1$ & 0.1 & 0.5 & 1 & 0.1 & 0.4 & 0.1 & 0.3 \\
\hline Spongiobranchaea australis & 0 & 0 & $<0.1$ & $<0.1$ & $<0.1$ & $<0.1$ & 0 & 0 & 0 & 0 \\
\hline Clione antarctica & $<0.1$ & 0.6 & $<0.1$ & 0.1 & $<0.1$ & $<0.1$ & 0 & 0 & 0.1 & $<0.1$ \\
\hline Limacina helicina & $<0.1$ & 0.2 & 0.7 & 0.6 & 0.1 & 0.2 & 0.3 & 0.2 & 1.2 & 0.9 \\
\hline Rhinchonerella bongraini & $<0.1$ & 0.2 & $<0.1$ & 0.1 & 0 & 0 & 0 & 0 & 0 & 0 \\
\hline Pelagobia longicerrata & 0.1 & 0.1 & 1.3 & 0.6 & 1.4 & 0.5 & 0.1 & 0.2 & 0.9 & 1.2 \\
\hline
\end{tabular}


Table 2. Cont.

\begin{tabular}{ccccccccccc}
\hline \multirow{2}{*}{ Species } & \multicolumn{2}{c}{ Cluster 1 } & \multicolumn{2}{c}{ Cluster 2 } & \multicolumn{2}{c}{ Cluster 3 } & \multicolumn{2}{c}{ Cluster 4 } & \multicolumn{2}{c}{ Cluster 5 } \\
& A & B & A & B & A & B & A & B & A & B \\
\hline Tomopteris spp. & $<0.1$ & $<0.1$ & $<0.1$ & $<0.1$ & 0.1 & $<0.1$ & $<0.1$ & $<0.1$ & $<0.1$ & $<0.1$ \\
Sagitta gazellae & $<0.1$ & $<0.1$ & $<0.1$ & 0.1 & $<0.1$ & 0.2 & 0 & 0 & $<0.1$ & $<0.1$ \\
Eukrohnia hamata & $<0.1$ & 0.3 & 0.1 & 0.7 & 0.2 & 0.6 & 0.1 & 0.3 & 0.1 & 0.5 \\
Medusae & $<0.1$ & 0.3 & $<0.1$ & 0.4 & 0 & 0 & 0 & 0 & $<0.1$ & 0.5 \\
Appendicularia & 0.1 & 0.1 & 0.1 & $<0.1$ & 0.5 & 0.2 & $<0.1$ & $<0.1$ & 0.4 & $<0.1$ \\
Salpa thompsoni & 0.1 & 7.2 & 0 & 0 & 0 & 0 & 0 & 0 & 0 & 0 \\
Pyrostephos vanhoeffeni & $<0.1$ & 4.4 & 0 & 0 & 0 & 0 & 0 & 0 & 0 & 0 \\
Calicopsis borchgervinki & 0 & 0 & 0 & 0 & $<0.1$ & 0.2 & 0 & 0 & 0 & 0 \\
Calianira sp. & 0 & 0 & 0 & 0 & $<0.1$ & 51.7 & $<0.1$ & 0.1 & 0 & 0 \\
Total abundance (mean \pm 1SD) & $1620 \pm 1124$ & $121.0 \pm 148.3$ & $164.2 \pm 86.6$ & $317.5 \pm 133.1$ & $419.1 \pm 218.8$ \\
Total biomass (mean \pm 1SD) & $26.2 \pm 20.1$ & $5.2 \pm 4.1$ & $13.8 \pm 22.6$ & $14.9 \pm 9.0$ & $8.0 \pm 8.3$ \\
\hline
\end{tabular}

SIMPROF routine confirmed that differences in composition between the five groupings, with the cluster and MDS analyses being significant $(p<0.01)$. Cluster 1 assemblage was numerically dominated ( $>95 \%$ of total abundance) by small copepods, mainly Oithona spp. (62\%), copepod naluplii $(17 \%)$, Ctenocalanus/Clausocalanus group (14\%) and Oncaea spp. (4\%) (Table 2); by biomass the same species dominated with the addition of R. gigas (14\%), S. thompsoni (7\%), T. macrura, and siphonophores (4\% each) (Table 2, Figure 11). Clusters 2 and 3 had the lowest total abundance and by numbers dominated by small and large copepods (Figure 11). Cluster 2 assemblage was dominated (in descending order of species $>5 \%$ of abundance) by Oithona spp., copepod nauplii, Ctenocalanus/Clausocalanus, and C. acutus (Table 2). In terms of biomass, small copepods collectively accounted for $\sim 16 \%$ of the standing stock, while large copepods dominated samples: C. acutus (50\%), C. propinquus (19\%), and M. gerlachei (6\%) (Table 2). Cluster 3 assemblage, although numerically similar to previous one, had gelatinous, mostly cnidarian, zooplankton comprising most of the standing stock (52\%), while large and small copepods accounted for $\sim 30 \%$ and $\sim 10 \%$, respectively (Table 2, Figure 11). Assemblage belonging to cluster 4 was numerically dominated by small copepods followed by large copepods and euphausiids (Figure 11), but by biomass, large copepods, mainly C. propinquus $(>50 \%)$, and calyptopis larvae of E. superba (11\%) were most important contributors to the zooplankton standing stock (Figure 11; Table 2 ). Similar to cluster 1 , numerically small copepods ( $>80 \%$ ) followed by large copepods dominated cluster 5 assemblage (Figure 11). This cluster was different from others because amphipods, mainly Themisto gaudichaudii, contributed nearly $10 \%$ of the total zooplankton standing stock (Table 2).

\section{Discussion}

Presented data, in general, reflects the community composition and dynamic seasonal pattern of zooplankton in the region south of the Antarctic Convergence described in the literature [5,18-21]. It should however, be pointed out that while average densities and biomass levels were within the documented range, it was on the higher side of the estimates. This can be explained by a $100 \mu \mathrm{m}$ mesh used in this study. In comparison, the majority of other estimates were obtained with nets equipped with mesh $\geq 200 \mu \mathrm{m}[18,22-25]$. It has been shown that in general, a $200 \mu \mathrm{m}$ mesh net retains on average $\sim 20 \%$ and $\sim 40 \%$ less biomass and abundance, respectively, compared to a similarly designed $100 \mu \mathrm{m}$ mesh net [26]. Indeed much higher $\left(>5000\right.$ ind $\left.\mathrm{m}^{-3}\right)$ epipelagic zooplankton densities have also been documented, but those were coincident with high numbers of pteropods or euphausiid larvae [27-29]. Overall, the distribution of zooplankton varied considerably and generally had low abundances at the southernmost stations, while generally opposite trend was observed for total biomass. It is linked to the copepod community composition and occasional catch of a single macroplankton organism. In addition, closer to the continent, the majority large calanoid species dominated by adults ready for spawning.

There was no surprise that large copepods C. acutus, C. propinquus, and M. gerlachei generally dominated the zooplankton biomass and small copepods accounted for the majority of the zooplankton 
abundance in the top $100 \mathrm{~m}$ layer of water [5,19,30-32]. The macrozooplankton could have been largely under-sampled by the net with a small mouth area and fine mesh size that is designed to sample mesozooplankton. Following Baker's [8] predictions, the community composition was differentiated according to the sampling latitude and/or season rather than longitudinally. The main composition of copepods and their development followed spatial and temporal patterns described by Voronina [33] for the whole Southern Ocean. Similar regional specifics have also been documented in various sectors of the Southern Ocean, e.g., the Ross Sea and western Amundsen Sea [10,13,27], the Weddell Sea [30,34,35], and the Cosmonaut Sea and the Prydz Bay Region [9,19,31,36-38].

A few observations are noteworthy. First, the substantial contribution of the pelagic tunicate S. thompsoni to the total abundance and biomass in the northeastern Ross Sea region. The salps were dominated by the small-sized blastozooids (aggregate forms), indicating recent asexual reproduction in the area, which was already ongoing in November 2017. This species was never encountered throughout the remaining survey until the end of the sampling season in April 2018. Second, while C. acutus was prominent across all surveys, both $M$. gerlachei and C. propinguus were most abundant and prevalent in the eastern part of the sampling area, particularly towards the austral fall. Third, there was a close coincidence, in both western and eastern surveys, of high small copepod numbers and samples dominated by the phytoplankton. While phytoplankton concentrations were not directly quantified, samples with large quantities of phytoplankton are a good proxy of the phytoplankton bloom conditions. Therefore, high quantities of small copepods and nauplii may have occurred either due to the net clogging at high phytoplankton concentrations that caused their better retention in the sample, or high phytoplankton densities could have been boosted copepod reproduction. We tend to favor the second explanation here. Fourth, Antarctic krill larvae were encountered only during the survey east of the South Orkney Islands. They had an unusually early developmental stage composition and were dominated by early ( 1 and 2 ) calyptopis stages, pointing to the late spawning season in 2017/18, which likely occurred at the beginning of March. The advanced stages (furcilia 1 to 3 ) were also present in the samples, but in very low numbers, and were likely indicators of spring/early summer krill spawning events. There is high uncertainty whether or not early krill larvae will be able to survive through the approaching winter, which may be a prerequisite for low krill recruitment during the next year. Finally, east of the South Orkney Islands, significant densities of the amphipod T. gaudichaudii were encountered; but was not observed in both the Ross and Amundsen Seas. Themisto is a carnivorous species contributing to mesozooplankton consumption [39,40]. It was also shown that this species might be an efficient predator on pelagic tunicates [41], thus responsible for decreasing zooplankton standing stock and salp population in the area.

In conclusion, it is important to emphasize that this pilot study opens new opportunities to investigate zooplankton dynamics using ships of opportunity in regions traditionally not sampled during the oceanographic surveys. These are preliminary results of the first such study, which could be further analyzed in-depth in follow up publications. Moreover, it will provide unprecedented opportunities to increase the seasonal and geographical zooplankton sampling coverage at a fraction of the cost of the full-scale oceanographic surveys. Such opportunities do not only provide invaluable information in regions that lack scientific efforts [12] but, more importantly, create an opportunity to establish and maintain international and hopefully long-term collaborations. In the end, such efforts would contribute a long way to supplement the already ongoing Southern Ocean continuous plankton recorder (SO-CPR) surveys and will be critical in monitoring long-term changes in the Southern Ocean pelagic ecosystem. Pilot studies like this could pave the way for building a long-term sampling program. Finally, a recently started initiative to model the Antarctic system will benefit from the additional information obtained in similar surveys.

Author Contributions: L.K.P. and E.A.P. conceptualized and designed the study. L.K.P. organized logistics for this study. A.K., V.P., I.S., and P.Z. collected samples. E.A.P. analyzed the samples and wrote the first draft of the manuscript. E.A.P. and L.K.P. reviewed and edited the MS. All authors have read and agreed to the published version of the manuscript. 
Funding: This research has been carried out as a collaboration between the University of British Columbia (Canada) and the Institute of Fisheries and Ecology (Ukraine). Both institutions contributed financially to the collection, analysis, and MS preparation.

Acknowledgments: We would like to thank the University of British Columbia (Canada) and the Institute of Fisheries and Ecology (Ukraine) for providing funds and facilities to complete this research. A continuous passion and support of the officers and crew onboard the Ukrainian longliners Calypso, Koreiz, Marigolds, and Simeiz contributed highly to the success of the austral summer 2018-19 sampling campaign.

Conflicts of Interest: The authors declare no conflict of interest.

\section{References}

1. Perry, R.I.; Batchelder, H.P.; Mackas, D.L.; Chiba, S.; Durbin, E.; Greve, W.; Verheye, H.M. Identifying global synchronies in marine zooplankton populations: Issues and opportunities. ICES J. Mar. Sci. 2004, 61, 445-456. [CrossRef]

2. Turner, J.T. The importance of small planktonic copepods and their roles in pelagic marine food webs. Zool. Stud. 2004, 43, 255-266.

3. Robert, D.; Murphy, H.M.; Jenkins, G.P.; Fortier, L. Poor taxonomical knowledge of larval fish prey preference is impeding our ability to assess the existence of a "critical period" driving year-class strength. ICES J. Mar. Sci. 2013, 71, 2042-2052. [CrossRef]

4. Steinberg, D.K.; Landry, M.R. Zooplankton and the Ocean Carbon Cycle. Annu. Rev. Mar. Sci. 2017, 9, 413-444. [CrossRef]

5. Atkinson, A.; Ward, P.; Hunt, B.P.V.; Pakhomov, E.A.; Hosie, G.W. An overview of Southern Ocean zooplankton data: Abundance, biomass, feeding and functional relationships. CCAMLR Sci. 2012, 19, 171-218.

6. Mantua, N.J.; Hare, S.R.; Zhang, Y.; Wallace, J.M.; Francis, R.C. A Pacific interdecadal climate oscillation with impacts on salmon production. Bull. Am. Meteorol. Soc. 1997, 78, 1069-1080. [CrossRef]

7. Rogers, A.; Frinault, B.; Barnes, D.; Bindoff, N.; Downie, R.; Ducklow, H.; Friedlaender, A.; Hart, T.; Hill, S.; Hofmann, E.; et al. Antarctic Futures: An Assessment of Climate-Driven Changes in Ecosystem Structure, Function, and Service Provisioning in the Southern Ocean. Annu. Rev. Mar. Sci. 2020, 12, 87-120. [CrossRef]

8. Baker, A.D.C. The circumpolar continuity of Antarctic plankton species. Discov. Rep. 1954, 27, 201-2018.

9. Makabe, R.; Tanimura, A.; Tamura, T.; Hirano, D.; Shimada, K.; Hashihama, F.; Fukuchi, M. Meso-zooplankton abundance and spatial distribution off Lützow-Holm Bay during austral summer 2007-2008. Polar Sci. 2017, 12, 25-33. [CrossRef]

10. Smith, W.O.; Delizo, L.M.; Herbolsheimer, C.; Spencer, E. Distribution and abundance of mesozooplankton in the Ross Sea, Antarctica. Polar Biol. 2017, 40, 2351-2361. [CrossRef]

11. Steinberg, D.K.; Ruck, K.E.; Gleiber, M.R.; Garzio, L.M.; Cope, J.S.; Bernard, K.S.; Stammerjohn, S.E.; Schofield, O.M.E.; Quetin, L.B.; Ross, R.M. Long-term (1993-2013) changes in macrozooplankton off the Western Antarctic Peninsula. Deep Sea Res. Part I Oceanogr. Res. Pap. 2015, 101, 54-70. [CrossRef]

12. Moriarty, R.; O'Brien, T.D. Distribution of mesozooplankton biomass in the global ocean. Earth Syst. Sci. Data 2013, 5, 45-55. [CrossRef]

13. Yang, E.J.; Lee, Y.; Lee, S. Trophic interactions of micro- and mesozooplankton in the Amundsen Sea polynya and adjacent sea ice zone during austral late summer. Prog. Oceanogr. 2019, 174, 117-130. [CrossRef]

14. Mizdalski, E. Weight and length data of zooplankton in the Weddell Sea in austral spring 1986 (ANT V/3). Ber. Polarforsch. 1988, 55, 1-72.

15. Clarke, K.R.; Warwick, R.M. Change in Marine Communities: An Approach to Statistical Analysis and Interpretation, 2nd ed.; PRIMAR-E: Plymouth, UK, 2001.

16. Field, J.; Clarke, K.R.; Warwick, R. A Practical Strategy for Analysing Multispecies Distribution Patterns. Mar. Ecol. Prog. Ser. 1982, 8, 37-52. [CrossRef]

17. Zar, J.H. Biostatistical Analysis, 4th ed.; Prentice Hall: Upper Saddle River, NJ, USA, 1999.

18. Stevens, C.J.; Pakhomov, E.A.; Robinson, K.V.; Hall, J.A. Mesozooplankton biomass, abundance and community composition in the Ross Sea and the Pacific sector of the Southern Ocean. Polar Biol. 2014, 38, 275-286. [CrossRef]

19. Swadling, K.M.; Kawaguchi, S.; Hosie, G.W. Antarctic mesozooplankton community structure during BROKE-West ( $30^{\circ}$ E-80 E), January-February 2006. Deep Sea Res. Part II Top. Stud. Oceanogr. 2010, 57, 887-904. [CrossRef] 
20. Takahashi, K.T.; Hosie, G.W.; Odate, T. Intra-annual seasonal variability of surface zooplankton distribution patterns along a $110^{\circ} \mathrm{E}$ transect of the Southern Ocean in the austral summer of 2011/12. Polar Sci. 2017, 12, 46-58. [CrossRef]

21. Takahashi, K.T.; Ojima, M.; Tanimura, A.; Odate, T.; Fukuchi, M. The vertical distribution and abundance of copepod nauplii and other micro- and mesozooplankton in the seasonal ice zone of Lützow-Holm Bay during austral summer 2009. Polar Biol. 2016, 40, 79-93. [CrossRef]

22. Voronina, N.M.; Kosobokova, K.N.; Pakhomov, E.A. Size structure of Antarctic metazoan plankton according to united net, trawl and water bottle data. Russ. J. Aquat. Ecol. 1994, 3, 137-142.

23. Voronina, N.M.; Kosobokova, K.N.; Pakhomov, E.A. Composition and biomass of summer metazoan plankton in the 0-200 m layer of the Atlantic sector of the Antarctic. Polar Biol. 1994, 14, 91-95. [CrossRef]

24. Errhif, A.; Razouls, C.; Mayzaud, P. Composition and community structure of pelagic copepods in the Indian sector of the Antarctic Ocean during the end of the austral summer. Polar Biol. 1997, 17, 418-430. [CrossRef]

25. Boysen-Ennen, E.; Hagen, W.; Hubold, G.; Piatkowski, U. Zooplankton biomass in the ice-covered Weddell Sea, Antarctica. Mar. Biol. 1991, 111, 227-235. [CrossRef]

26. Gallienne, C.P.; Robins, D.B. Is Oithona the most important copepod in the world's oceans? J. Plankton Res. 2001, 23, 1421-1432. [CrossRef]

27. Makarov, R.R.; Men'shenina, L.L.; Spiridonov, V.A. Plankton distribution and its seasonal biological activity in the central and western parts of the Antarctic Pacific Sector. In Oceanographic and Biological Investigations of the Pacific Antarctic Sector (Biologo-Okeanographicheskie Issledovanija Tihookenaskogo Sektora Antaktiki); Makarov, R.R., Dolzhenkov, V.N., Ljubimova, T.G., Spiridonov, V.A., Tarverdieva, T.G., Eds.; VNIRO Publishers: Moscow, Russia, 1987; pp. 90-110. (In Russian)

28. Pane, L.; Feletti, M.; Francomacaro, B.; Mariottini, G.L. Summer coastal zooplankton biomass and copepod community structure near the Italian Terra Nova Base (Terra Nova Bay, Ross Sea, Antarctica). J. Plankton Res. 2004, 26, 1479-1488. [CrossRef]

29. Hunt, B.; Pakhomov, E.; Hosie, G.; Siegel, V.; Ward, P.; Bernard, K. Pteropods in Southern Ocean ecosystems. Prog. Oceanogr. 2008, 78, 193-221. [CrossRef]

30. Hopkins, T.L.; Torres, J.J. The zooplankton community in the vicinity of the ice edge, western Weddell Sea, March 1986. Polar Biol. 1988, 9, 79-87. [CrossRef]

31. Hosie, G.W.; Cochran, T.G.; Pauly, T.; Beaumont, K.L.; Wright, S.W.; Kitchener, J.A. The zooplankton community structure of Prydz bay, January-February 1993. Proc. NIPR Symp. Polar Biol. 1997, 10, 90-133.

32. Yang, G.; Li, C.; Sun, S. Inter-annual variation in summer zooplankton community structure in Prydz Bay, Antarctica, from 1999 to 2006. Polar Biol. 2011, 34, 921-932. [CrossRef]

33. Voronina, N.M. Pelagic Ecosystems of the Southern Ocean; Nauka Press: Moscow, Russia, 1984; p. 206. (In Russian)

34. Fedotova, V.V.; Gorlanova, O.L. Peculiarities of the mesoplankton distribution in the Ross Sea in summer 1983. In Oceanographic and Biological Investigations of the Antarctic Pacific Sector (Biologo-Okeanographicheskie Issledovanija Tihookenaskogo Sektora Antaktiki); Makarov, R.R., Dolzhenkov, V.N., Ljubimova, T.G., Spiridonov, V.A., Tarver-dieva, T.G., Eds.; VNIRO Publishers: Moscow, Russia, 1987; pp. 80-90. (In Russian)

35. Makarov, R.R.; Solyankin, E.V. Abundant copepods and regional peculiarities of their seasonal development in the east area of the Weddell Gyre. In Investigations of the Weddell Gyre. Oceanographic Conditions and Peculiarities of the Development of Plankton Communities; Solyankin, E.V., Ed.; VNIRO Press: Moscow, Russia, 1990; pp. 99-125. (In Russian)

36. Bundichenko, E.V.; Khromov, N.S. Mesoplankton biomass, age composition and distribution of dominant species in relation to water structure in the Commonwealth and the Cosmonaut Seas. In Interdisciplinary Investigations of Pelagic Ecosystem in the Commonwealth and Cosmonaut Seas; Lubimova, T.G., Makarov, R.R., Maslennikov, V.V., Samyshev, E.Z., Bibik, V.A., Tarverdieva, T.G., Eds.; VNIRO Publishers: Moscow, Russia, 1988; pp. 83-109. (In Russian)

37. Bunichenko, E.V. Change in age composition of the abundant copepod species in the Cooperation Sea in 1977-1990. Oceanol. Russ. Acad. Sci. 1994, 34, 252-258. (In Russian)

38. Yang, G.; Li, C.; Wang, Y.; Zhang, Y. Vertical profiles of zooplankton community structure in Prydz Bay, Antarctica, during the austral summer of 2012/2013. Polar Biol. 2017, 40, 1101-1114. [CrossRef]

39. Pakhomov, E.A.; Perissinotto, R. Trophodynamics of the hyperiid amphipod Themisto gaudichaudii in the South Georgia region during late austral summer. Mar. Ecol. Prog. Ser. 1996, 134, 91-100. [CrossRef] 
40. Froneman, P.W.; Pakhomov, E.A.; Treasure, A. Trophic importance of the hyperiid amphipod, Themisto gaudichaudii, in the Prince Edward Archipelago (Southern Ocean) ecosystem. Polar Biol. 2000, 23, 429-436. [CrossRef]

41. Kruse, S.; Pakhomov, E.A.; Hunt, B.; Chikaraishi, Y.; Ogawa, N.; Bathmann, U. Uncovering the trophic relationship between Themisto gaudichaudii and Salpa thompsoni in the Antarctic Polar Frontal Zone. Mar. Ecol. Prog. Ser. 2015, 529, 63-74. [CrossRef] 